\title{
Ecdeiocolea rigens, a new species of Ecdeiocoleaceae (Poales) from Western Australia
}

\author{
Barbara G. Briggs ${ }^{1}$ \\ Botanic Gardens Trust Sydney, Mrs Macquaries Road, Sydney NSW 2000, Australia. \\ Email: barbara.briggs@rbgsyd.nsw.gov.au
}

\begin{abstract}
Ecdeiocolea rigens B.G.Briggs is described and illustrated, being the second species of its genus and third species recognised in Ecdeiocoleaceae. E. rigens is abundant on sand plains in a region north and east of Geraldton in the west of Western Australia. It occurs sympatrically, without evidence of intergradation, with the more widespread E. monostachya F. Muell. and is distinguished by its extensively rhizomatous habit, larger size and rigid culms. Brief comment is made on culm anatomy and DNA findings. A lectotype is selected for E. monostachya.
\end{abstract}

\section{Introduction}

Ecdeiocoleaceae have recently come to unexpected notice as possibly the closest living relatives of Poaceae. The close relationship of Ecdeiocoleaceae to Poaceae, rather than to Restionaceae, was first indicated by Briggs et al. (2000). The clade of Joinvilleaceae, Ecdeiocoleaceae and Poaceae is robustly supported by DNA data (Bremer 2002; Michelangeli et al. 2003; Chase 2004; Hilu 2004; Chase et al. 2006; Givnish et al. 2006; Marchant \& Briggs 2007; Bouchenak-Khelladi et al. 2008; Givnish et al. in press). This clade, however, remains unresolved or resolves in conflicting ways in analyses based on different plastid DNA data and in analyses using different methods (Saarela \& Graham 2010; Briggs et al. 2010). The extensive diversification and worldwide extent of Poaceae are in sharp contrast to their sister groups with only one genus of two species in Joinvilleaceae and, until now, two monotypic genera in Ecdeiocoleaceae.

Features of Ecdeicoleaceae were described by Linder et al. (1998) and also, for reproductive structures, by Rudall et al. (2005). These include the highly xeromorphic anatomy of the culms (Cutler \& Airy Shaw 1965; Cutler 1969) with a sub-epidermal sclerenchyma layer and stomates protected at the base of deep longitudinal grooves which divide the chlorenchyma into longitudinal segments. Leaves are reduced or absent in adult plants. The structure of the inflorescence of these monoecious plants

${ }^{1}$ This paper is dedicated to the memory of my colleague Dr Surrey Jacobs recognising especially his major contributions to the systematics and phylogeny of Poaceae and his enthusiasm for field studies of Australian plants. 
is also common to all members of the family, with male and female flowers in zones that open progressively up the spike, the basal zone being of female flowers; the flowers are wind-pollinated with exserted anthers or feathery stylar branches. Features of Ecdeiocolea include: culms consisting of a single long internode with one persistent sheath high on the culm (at the base of the peduncle which is more slender than the culm), spike solitary, flowers with six tepals and four stamens; ovary at first 2-locular but only one loculus and one seed developing; stylar branches two; fruit a nut. The other genus recognised in the family, Georgeantha B.G.Briggs \& L.A.S.Johnson, differs in having several culm nodes with caducous sheaths, some elongation of the leaf lamina, a branched inflorescence with two or several spikes, and dehiscent 3-locular capsular fruits (Briggs \& Johnson 1998). Also, in Georgeantha, the sub-epidermal sclerenchyma is connected to the outer vascular bundles by a sclerenchyma rib through the centre of each chlorenchyma segment. Ecdeiocolea monostachya F.Muell. and G. hexandra B.G.Briggs \& L.A.S.Johnson are described and illustrated in Meney et al. (1999).

\section{Typification of Ecdeiocolea monostachya}

Before describing E. rigens as new, it has been necessary to confirm the identity of the syntypes of E. monostachya, especially since some are from the Murchison River in Western Australia, where E. rigens also occurs. The opportunity is taken to select a lectotype for E. monostachya.

Ecdeiocolea monostachya F.Muell. (Mueller 1874: 236):

Lectotype, here designated: Drummond 2nd collection 342 (MEL 15088!; isolectotypes MEL 15087!, Drummond Swan River K!). Syntypes: Murchison River, Oldfield (MEL 15086!, 15089!), 'thick clumps, sand Plain near G'nia, Murchison R, W. Australia', Oldfield (K! $[2$ sheets]).

\section{Taxonomy}

Ecdeiocolea rigens B.G.Briggs, sp. nov.

Ab Ecdeiocolea monostachya combinatione characterum sequentium distinguitur: habitus rhizomati longi, culmi rigidi, ad $1.8 \mathrm{~m}$ longi, basi (1.5)2-3 mm diametro, plerumque in rhizomate per 5-20 mm. separati, spicae florenti latior, 7-12 mm diametro.

Type: Western Australia: E side of Wandin Creek, 600m S of Campbells Rd, SE of East Yuna, WNW of Mullewa $\left(28^{\circ} 25^{\prime} 04^{\prime \prime S}, 115^{\circ} 10^{\prime} 59^{\prime \prime E}\right)$, B.G. Briggs 9904, 19 Oct 2008 (holo NSW 783187; iso AD, BRI, CANB, HO, L, LE, MEL, MO, NY, PERTH, PRE, Z).

Monoecious, rhizomatous herb with sand-binding roots; forming dense patches or spread diffusely over areas up to $2 \mathrm{~m}$ across. Rhizomes to $15 \mathrm{~cm}$ or more long, 4-6 mm diam., with tufts of long $(3-6 \mathrm{~mm})$ hairs covered by glabrous cataphylls. Basal sheaths persistent, mostly dull brown, paler toward the apex, to $22 \mathrm{~cm}$ long, 5-8 $\mathrm{mm}$ broad. Culms mostly spaced 5-20 $\mathrm{mm}$ apart on the rhizome (though sometimes more crowded), terete, rigid, striate, to $1.8 \mathrm{~m}$ tall, each bearing a single cauline bract and single spike; near the base (1.5-)2-3 mm diam. (measured when dry), narrowing above to $1.2-1.5 \mathrm{~mm}$ diam.; toward the base with a white powdery coating; cauline bract scarious, c. $3 \mathrm{~cm}$ long; peduncle (above the bract) to $15 \mathrm{~cm}$ long, 0.8-1.3 mm diam. Spike: 20-45 $\mathrm{mm}$ long, 7-12 $\mathrm{mm}$ wide, the axis with long pale 
hairs; zones of female and of male flowers alternating once or twice towards the apex depending on spike development which varies greatly with seasonal conditions; the most basal zone being of female flowers; flowers each solitary in the axil of a bract; bracts spirally arranged in 5 ranks; in good seasons the spike with 30-45 flowers (fewer or wholly aborted in drought seasons), each rank with 7-9 flowers (each rank with 1or 2 female flowers at the base, above them 4-8 males, and 1 or 2 females toward the apex). Floral bracts: ovate-cuneate, brown, firm, dull or slightly glossy, 5-7 mm long. Flowers: on very short pedicels, tepals 6, c. $6 \mathrm{~mm}$ long, scarious to hyaline, with infolded margins toward the rounded apex; outer tepals keeled, inner tepals \pm flat. Male flowers: distinguished externally from the females by the lateral tepals densely ciliate on the keel toward the apex with branching multicellular hairs to $0.5 \mathrm{~mm}$ long; anthers c. $3 \mathrm{~mm}$ long; pistillode present. Female flowers: tepals glabrous; staminodes minute;

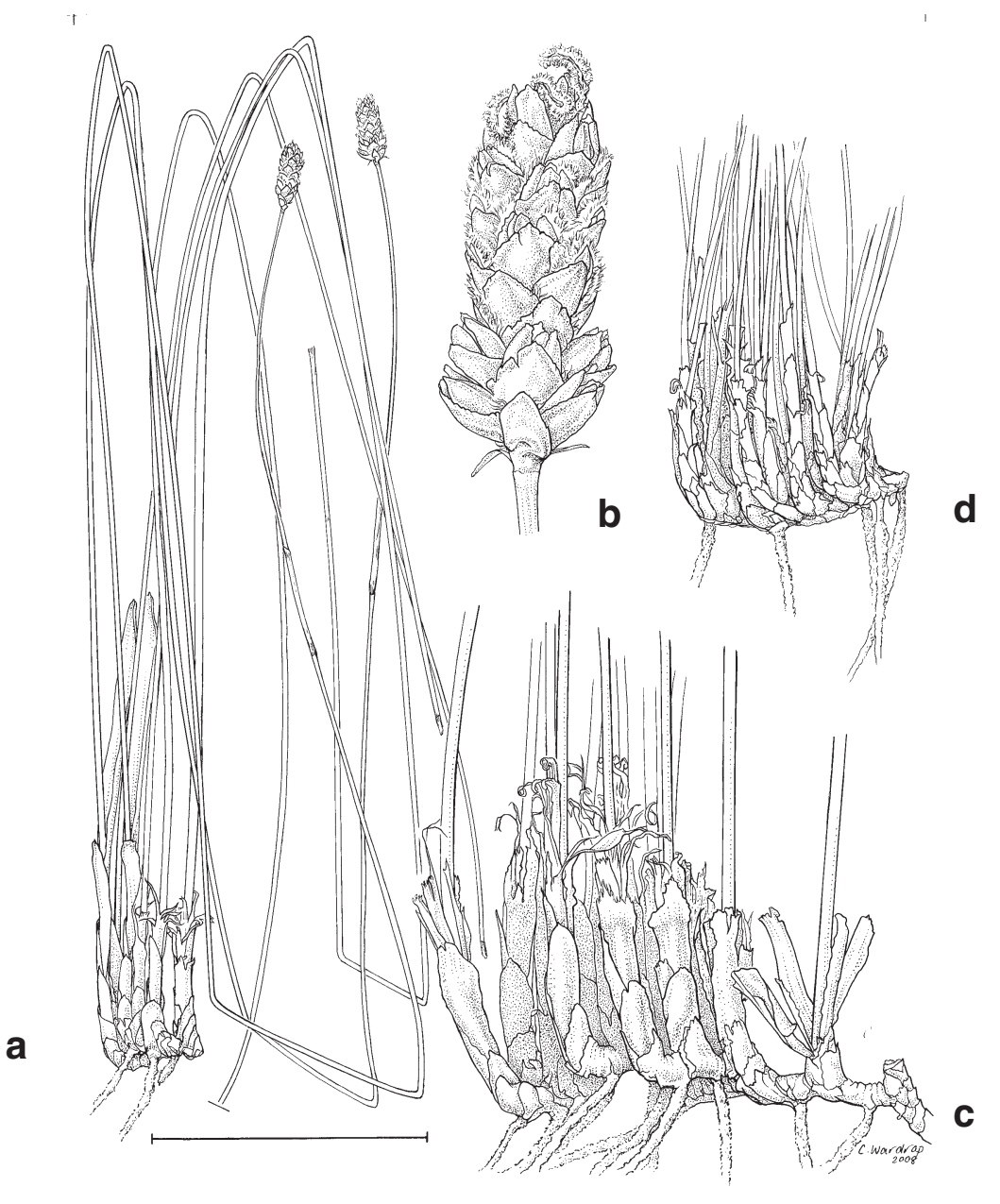

Fig. 1. a-c Ecdeiocolea rigens a, habit. b, spike. c, rhizome, cataphylls and culm bases, showing separation between most culm bases. d, E. monostachya, part of tussock base showing crowded culm bases and slender culms. a, b, from R.V. Smith 66/281 (NSW 406461); c, Briggs 9852; d, Briggs 9853 (3 km S of Hawkes Head Lookout, Kalbarri National Park, 22 Nov 2007 [NSW 757772]). Scale bar: $\mathrm{a}=9 \mathrm{~cm} ; \mathrm{b}=1.5 \mathrm{~cm} ; \mathrm{c}, \mathrm{d}=5 \mathrm{~cm}$. 
stylar branches 2, very shortly united. Fruit a nut, 4-5 mm long, $3 \mathrm{~mm}$ wide, globular with a wrinkled, blunt apical beak; shed with tepals attached and pedicel c. $1 \mathrm{~mm}$ long. Seeds white, globular, finely ridged. (Fig. 1)

Distinguished from E. monostachya by the extensively rhizomatous habit (Fig. 2), so that plants form widely-spaced clumps or lines of culms; cataphylls brown and less glossy; culms stouter, more rigid and generally taller; spikes broader. The contrasting features of E. monostachya are: caespitose habit with large dense tussocks of crowded culms, cataphylls tan and glossy; culms to $1-1.5(-1.8) \mathrm{mm}$ diam. near the base and $0.5-1 \mathrm{~m}$ tall; spikes $4.5-6 \mathrm{~mm}$ diam.
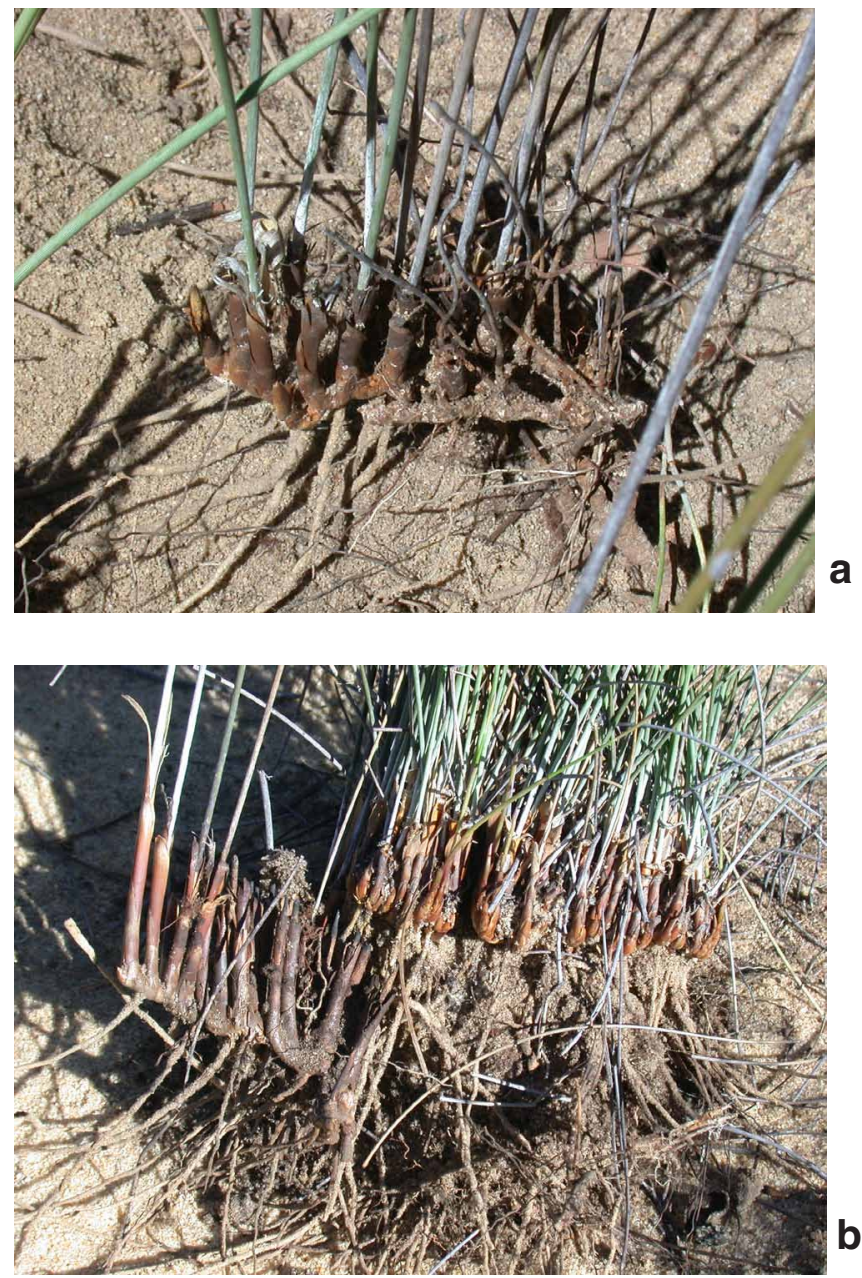

Fig. 2. Rhizomes of Ecdeiocolea rigens and comparison with E. monostachya. a, rhizome with culm bases of Ecdeiocolea rigens excavated in the field. b, rhizome with culms of Ecdeiocolea rigens (lower left) placed beside slender-culmed dense tussock of E. monostachya (upper right). The older culm bases of E. rigens have been charred by fire. Photos by P. Meagher from the site of collection of Briggs 9696, 9697 and 9701, where the two species occur intermixed. 
This taxon was previously known by the informal phrase name 'Ecdeiocolea sp. Rigid (R.V. Smith 66/281)' (Western Australian Herbarium: FloraBase 1998+).

Etymology: the epithet refers to the rigid culms which are usually stiffly erect: rigens $($ Latin $)=$ stiff, rigid.

Culm anatomy: similar to E. monostachya but large sclereids in the chlorenchyma are more common than in E. monostachya; the sub-epidermal sclerenchyma is deeper; and larger strands of sclerenchyma surround the vascular bundles, extending radially inwards and outwards from the vascular bundle.

Chloroplast DNA sequence data: Briggs et al. (2010) reported that $\operatorname{trn} \mathrm{L}-\mathrm{F}$ sequences of E. monostachya and E. rigens are identical and only nine bases differ in the trnK sequences .

Distribution and flowering : Western Australia: mostly Geraldton Sandplains but also edge of Avon Wheatbelt and Yalgoo. In Kalbarri National Park and north and east of Geraldton from Eurardy towards Mullewa in the west of Western Australia, on sandplains of yellow sand and in shrubland in a region of low rainfall. Commonly occurring intermixed with the more widespread E. monostachya. Since there is no geographic or ecological separation, the reproductive isolation of these wind-pollinated species is of interest. There have been insufficient observations to establish whether there is a difference in flowering time but any such difference is probably minimal. Specimens of $E$. rigens show pre-anthesis spikes or flowering in August, and developing or mature fruits in October. Flowering of E. monostachya ranges from August to October, with peak flowering in September.

Conservation status: reasonably widespread and often abundant; not endangered. Resprouting after fire.

Selected specimens examined (sequence north to south): Western Australia: Irwin: Nerren Nerren Station, J.S. Beard 6753, 08 Oct 1973 (NSW, PERTH); North West Coastal Highway 24.6 km north of Kalbarri turn off, B.G. Briggs 9710, 27 Aug 2006 (NSW, PERTH); Kalbarri National Park, 28.8 km northwest of North West Coastal Highway on Ajana-Kalbarri Road, B.G. Briggs 9696, 9697, 9701, 26 Aug 2006 (NSW, PERTH); 3 km by road south of Hawkes Head lookout, beside road towards Ajana-Kalbarri Road, B.G. Briggs 9852, 22 Nov 2007 (NSW, PERTH); Kalbarri-Ajana Road, 9.6 km SE of National Park boundary, B.G. Briggs 9707, 27 Aug 2006 (AD, CANB, DNA, K, KYO, MO, NSW, NY, PERTH); 10 miles [16 km] along North West Highway towards Kalbarri, C.H. Gittins 1566, Aug 1967 (NSW, PERTH); North West Coastal Highway, 7 miles [c. $11 \mathrm{~km}$ ] N of Murchison River Bridge, R.V. Smith 66/281, Sep 1966 (NSW, MEL, PERTH); Kirralee Farm, Brooke Road, Ajana, $10 \mathrm{~km}$ E of North West Coastal Highway, G. \& P. Allan 52, 27 Aug 2001 (PERTH); Peter Road, 1 km N of Old Geraldton Road, W of Mullewa, B.G. Briggs 9901, 9902, 19 Oct 2008 (NSW, PERTH).

\section{Acknowledgments}

I thank Alex George who first drew my attention to the distinctiveness of Ecdeiocolea plants in the area of this species, Peter Wilson for assistance with the Latin diagnosis, Catherine Wardrop for the illustration, Patricia Meagher for the photographs, and Neville Walsh for observations on type specimens of E. monostachya in MEL. Joint fieldwork with Patricia Meagher and with Russell Barrett gave information and valuable insights, as did associated DNA sequencing studies by Adam Marchant. The opportunity to examine specimens on loan or in other herbaria assisted the work. 


\section{References}

Bouchenak-Khelladi Y, Salamin N, Savolainen V, Forest F, van der Bank M, Chase MW \& Hodkinson TR (2008) Large multi-gene phylogenetic trees of the grasses (Poaceae): progress towards complete tribal and generic level sampling. Molecular Phylogenetics and Evolution 47: 488-505.

Bremer K (2002) Gondwanan evolution of the grass alliance of families (Poales). Evolution 56: $1374-1387$.

Briggs BG \& Johnson LAS (1998) Georgeantha hexandra, a new genus and species of Ecdeiocoleaceae (Poales) from Western Australia. Telopea 7: 307-312.

Briggs BG, Marchant AD, Gilmore S \& Porter CL (2000) A molecular phylogeny of Restionaceae and allies. Pp. 661-671 in Wilson, KL \& Morrison, D (eds.) Monocots-Systematics and Evolution. (CSIRO: Melbourne)

Briggs BG, Marchant AD \& Perkins AJ (2010) Phylogeny and features in Restionaceae, Centrolepidaceae and Anarthriaceae (restiid clade of Poales). Pp. 358-388 in Seberg O, Petersen G, Barford AS \& Davis JI (eds) Diversity, Phylogeny and Evolution in the Monocotyledons. (Aarhus University Press)

Chase MW (2004) Monocot relationships: an overview. American Journal of Botany 91: 1645-1655.

Chase MW, Fay MF, Devey DS, Maurin O, Rønsted N, Davies TJ, Pillon Y, Petersen G, Seberg O, Tamura MN, Asmussen CB, Hilu K, Borsch T, Davis JI, Stevenson DW, Pires JC, Givnish TJ, Sytsma KJ, McPherson MA, Graham SW, \& Rai HS (2006) Multi-gene analyses of monocot relationships: a summary. Monocots: Comparative Biology and Evolution (excluding Poales). Aliso 22: 63-75.

Cutler DF (1969) Juncales. Pp. 1-357 in Metcalfe CR (ed) Anatomy of the Monocotyledons. (Clarendon Press: Oxford)

Cutler DF \& Airy Shaw HK (1965) Anarthriaceae and Ecdeiocoleaceae: two new monocotyledonous families, separated from Restionaceae. Kew Bulletin 19: 489-499.

Givnish TJ, Pires JC, Graham SW, McPherson MA, Prince LM, Patterson TB, Rai HS, Roalson EH, Evans TM, Hahn WJ, Millam KC, Merow AW, Molvray M, Kores PJ, O’Brien HE, Hall JC, Kress WJ \& Sytsma KJ (2006) Phylogenetic relationships of monocots based on the highly informative plastid gene $n d h \mathrm{~F}$ : evidence for widespread concerted convergence. Aliso 22: $28-51$.

Givnish TJ, Leebens-Mack JH, Sevillano MA, McNeal JR, Steele PR, Davis JI, Ané C, dePamphilis CW, Gandolfo MA, Graham SW, Pires JC, Stevenson DW, Zomlefer WB, Briggs BG, Clark LG, Duvall MR, Moore A, Moore M, Soltis DE, Soltis PS \& Thiele K (in press) Assembling the tree of the monocotyledons: plastome phylogeny and evolution of order Poales. Annals of the Missouri Botanical Garden.

Hilu KW (2004) Phylogenetics and chromosomal evolution in the Poaceae (grasses). Australian Journal of Botany 52: 13-22.

Linder HP, Briggs BG \& Johnson LAS (1998) Ecdeiocoleaceae. Pp. 425-445 in Kubitski K (ed.) The Families and Genera of Flowering Plants IV Monocotyledons. (Springer-Verlag: Berlin)

Marchant AD \& Briggs BG (2007) Ecdeiocoleaceae and Joinvilleaceae, sisters of Poaceae (Poales): evidence from rbcL and matK data. Telopea 11: 437-450.

Meney KA, Pate JS \& Hickman EJ (1999) Morphological and anatomical descriptions of Restionaceae and allied families and their distribution. Pp. 161-461 in Meney KA \& Pate JS (eds) Australian Rushes, Biology, Identification and Conservation of Restionaceae and allied families. (University of Western Australian Press: Nedlands)

Michelangeli FA, Davis JI \& Stevenson DW (2003) Phylogenetic relationships among Poaceae and related families as inferred from morphology, inversions in the plastid genome, and sequence data from the mitochondrial and plastid genomes. American Journal of Botany 90 : 93-106. 
Mueller F. (1874) Fragmenta Phytographice Australice, vol. 8: 236. (Government Printer: Melbourne)

Rudall PJ, Stuppy W, Cunniff J, Kellogg EA \& Briggs BG (2005) Evolution of reproductive structures in grasses (Poaceae) inferred by sister-group comparison with their putative closest living relatives, Ecdeiocoleaceae. American Journal of Botany 92: 1432-1443.

Saarela JM \& Graham SW (2010) Inference of phylogenetic relationships among the subfamilies of grasses (Poaceae: Poales) using meso-scale exemplar-based sampling of the plastid genome. Botany 88: 65-84.

Western Australian Herbarium (1998+) FloraBase - The Western Australian Flora. Department of Environment and Conservation. http://florabase.dec.wa.gov.au/ [accessed February 2010].

Manuscript received 9 February 2010, accepted 09 June 2010 